\title{
Development against poverty: A systemic model design based on empirical evidence
}

\author{
Heriberto E. Cuanalo de la Cerda \\ Human Ecology. Cinvestav. Mérida Unit \\ Mérida, Yucatán. México \\ cuanalo@mda.cinvestav.mx
}

Received: January 14, 2019. Revised: September 22, 2021. Accepted: October 1, 2021. Published: November $13,2021$.

\begin{abstract}
The world's poor numbered almost 2.8 billion in 2001, and 2.5 billion in 2005. During a decade of participatory research in a village in Yucatan, Mexico, we built a systemic model of transition from poverty to wellbeing. Households are the basic units because they are the source of human biological and cultural reproduction. Poverty is characterized by low levels of basic needs (i.e. education, health, income and capital). We applied a strategy of innovation and multiple goals, and exploited interaction between variables, in successive approaches within time cycles. Model application improved child nutrition, investment and savings, and credits levels
\end{abstract}

Keywords—Social development; poverty; households; basic needs; Maya; Yucatan.

\section{INTRODUCTION}

Of the estimated 2001 world population of 6 billion, about 2.8 billion (almost half) lived on less than USD \$2 a day and 1.2 billion (a fifth) lived on less than USD\$ 1 a day [1]. A large portion of the world's population suffers intense poverty while another portion enjoys the luxury of plenty. After four years of continued population growth, this proportion remained constant despite spectacular economic growth in China and Southeast Asia and perhaps partially due to minimal growth in many other areas, particularly sub-Saharan Africa. Using a more current and realistic poverty threshold of USD \$2 a day, those in extreme poverty increased to 2.5 billion [2]. Reference [3] estimated that $47 \%$ of households in Mexico are poor. Different sources agree that poverty in the world and Mexico is a serious problem. The challenge of poverty continues to grow in Mexico with increases from 2006 to 2008 of 44.7 to 50.6 million Mexicans in patrimony poverty and 14.4 to 19.5 million without enough income to eat [4]. In 2010, there were 52.0 million Mexicans in poverty and 11.7 million in extreme poverty [5]. The World Bank [1] and the Mexican government [6] implement poverty alleviation programs, although these are defined at a macro-economic level and are rarely reflected in concrete actions aimed at ameliorating the causes of household poverty.

References [7] and [8] propose a shift in development by first acknowledging that development is a dynamic, often cyclical open-ended process driven by a large number of variables. Interactions between these variables generate a stable organization that cannot be imposed by external agents. Other studies highlight the complexity of rural transformation in the Philippines and Africa [9]; [10].
Here I describe construction of a conceptual systemic model of development against poverty based on participatory (action) research [11], in a poor Maya community in Yucatan state, Mexico. The qualitative results behave as a complex system [12], [13] and I present them as such.

\section{METHODOLOGY}

Based on previous research [14], the village of Yaxcabá was chosen for this analysis because it is in the poorest region of the state of Yucatan, on the Yucatan Peninsula, Mexico. Yaxcabá village is located approximately $120 \mathrm{~km}$ east of the state capitol of Merida and about $20 \mathrm{~km}$ west of Chichen Itza. Its population has remained near 3000 during the last ten years [15]. Birth rates are relatively high in Yaxcabá, with an average of six children per family, but its population has not increased, mainly due to emigration of young adults. The population is distributed in about 500 households, most of which consist of nuclear families in poverty. Like many other villages in the region, the inhabitants of Yaxcaba are of ethnic Maya and Spanish descent, and speak Yucatec Maya as their first language and Spanish as a second language.

Regional climate is sub-humid tropical with mean annual temperature of $26{ }^{\circ} \mathrm{C}$ (temperatures below $5{ }^{\circ} \mathrm{C}$ are extremely rare) and average annual rainfall of $1200 \mathrm{~mm}$ with a distinct six-month dry season. The landscape is a limestone platform with elevations varying from 3 to $10 \mathrm{~m}$. Elevated areas account for approximately $70 \%$ of the surface and have rocky soils, while the bottoms are flat areas smaller than 1 hectare with deep, red clay soils. Soil distribution limits the use of medium-size mechanical equipment and machinery. The region lacks flowing surface water because rainfall quickly filters through the porous limestone bedrock to the aquifer at a depth of about $23 \mathrm{~m}$. Dissolution of the bedrock forms caverns which eventually collapse, forming sinkholes (locally known as cenotes) that provide access to the aquifer. For millennia, settlements have been established near sinkholes to take advantage of year round access to water, although most modern settlements now have municipal water systems supplied by deep wells. Agriculture in the area is predominantly slash-and-burn, although small irrigated areas are planted with oranges, lemons and other tropical fruit trees [16], [17].

\section{A. Communities, households and poverty}

Homo sapiens is a social species that naturally forms communities. Human communities have developed 
simultaneously with human culture, and now manifest significant sub-communities formed around aspects such as social status, religion, science and ideology. Each of these sub-communities often has a different leader and a distinct structure. A given individual may belong to different social status, religious and/or game-sport sub-communities, each with its own leader and structure. Within the social class structure, the poor are usually considered the lowest status sub-community.

Humans also group themselves in households or domestic groups [18], commonly consisting of a family. A household is a subsystem within a system of households. It is the basis for biological, economic and cultural reproduction and maintenance of the human species, and therefore constitutes the most basic unit of social development against poverty. It is in the household that humans manifest poverty and wellbeing. Development is a process by which people move from poverty to wellbeing or vice versa, that is, it can be negative or positive. Poverty is the development condition in which people have access to barely enough means to exist; it is the inter-phase between lack of the indispensable means for existence and household disintegration or migration. Wellbeing is understood as the condition in which human needs are met, in which one can act logically to meet personal goals and enjoy a satisfactory quality of life [19]. The study of development against poverty is a schema focused on providing people the opportunity to acquire the means necessary to exit the condition. For the present purposes, wellbeing is defined as the condition in which people partially or totally cover their basic needs. People's basic needs are many, but we have grouped them in five categories: education (self-esteem and leadership); physical and mental health (diet, disease prevention and treatment); income (for subsistence, productivity and employment); and capital (vulnerability, savings, credit and subsidies).

Unlike the concept proposed by many economists, poverty is not a chronic lack of income. If this were the case, it could be remediated merely by providing direct subsidies in emergency situations, the most common approach employed in government programs. These programs frequently help households to subsist but simultaneously increase their poverty by making them dependent on these subsidies. In reality, poverty is discouragement and ignorance, disease, insufficient production (income) to meet needs and high vulnerability (persistent low capital and income). As stated, wellbeing is a condition in which households meet their basic educational, health, income and safety needs.

\section{B. Participatory approach}

The project included joint activities between community members (households, leaders, government representatives) and researchers. This approach is known as participatory (action) research and has been used widely in community research [11], [20]. The participatory approach has largely replaced the positivist focus, which has been rejected for its insistence on clearly distinguishing between the object of research and the researcher (people are now viewed as research subjects rather than objects), and its assumption that science is an objective structure free from human values [21]. Reference [22] defined three basic assumptions which distinguish the participatory (action) research focus from the positivist: i) science is a social construct subject to interpretations, revisions and enrichment, with the main objective of generating knowledge useful to the problem of interest; ii) the objective of knowledge is to improve practice within the praxis/theory dialectic such that the researcher can become directly involved in and insert her/himself into the social process, thus revealing and establishing the truth through testimony, logic and direct observation; iii) researcher(s) and subject(s) are thinking people with feelings whose different points of view must be considered respectfully and with mutual appreciation, and data collected from collective encounters and group discussions are more interesting and trustworthy, and produce results with multiple references. Reference [23] also stated that participatory (action) research integrates the production and use of knowledge with the purpose of promoting learning among individuals and groups, normally characterized for being unique, uncertain and unstable.

In the present case, a series of interviews, training sessions and experimental actions were held with individuals and groups, building communities of learning and inquiry within communities of practice [23], [24]. This allowed us to build theories of action, combining interpretation with rigorous testing of these theories.

The participatory questions were formulated based largely on [23]. (i) What is the problem? That is, how do agents and researchers perceive the problem and what results do they hope to achieve. (ii) What do we know about the problem? Agents and researchers compare their knowledge. (iii) What can we do? A list is made of the different possible strategies to be followed. (iv) What are we going to do? Select and implement one or more strategies, based on available resources. (v) What results have we obtained so far? The actual outcome of these strategies as described mainly by the researchers and interpreted jointly by agents and researchers. (vi) What changes need to be made? And finally, (vii) how are we going to implement these changes? That is, what are agents and researchers going to do to modify the strategies? These questions were implemented in feedback cycles, eventually returning to "What is the problem? The actions generated experimental results which helped answer a number of the questions. The study focus adopted here is that of Freire [33], who proposed that the creation process of social reality must consider the concrete, as well as perceptions of the concrete

\section{Model construction}

The project which generated the data used to build the model was begun in 1995. At the beginning of the project, the research team provided a detailed explanation to the municipal authorities of Yaxcaba of project intent and work methodology. It was clearly stated that the researchers would function as advisors on production matters and the people 
would define the research themes. We assumed at first that the fight against poverty was essentially a matter of improving production technology, training producers in technological innovations and applying available subsidies. This approach functioned well in improving existing production systems. Training was provided in apiculture, and participative research conducted on the milpa agricultural system (combined cultivation of corn, beans and squash), irrigation agriculture and backyard vegetable and animal production. Treatments and experimental parcel sizes were agreed to among the producers and researchers, the producers carried out the work and the researchers recorded and analyzed the results; interpretation was done jointly [25], [26]. This process led to successful innovations in production systems for milpa crops, honey, orange, lemon, cucumber, habanero chili, poultry and swine. These innovations were expressed as cost/benefit ratios and the results presented by the producers to other community members and their authorities [16]. In 1996, the producers applied innovations using small subsidies from the Ministry of Social Development (Secretaría de Desarrollo Social SEDESOL). After two years of work, in 1997, the production and productivity of the most important food- and cashgenerating processes was raised through technological adaptation, participatory research, training and subsidies. Unfortunately, it was quite obvious that the extra income was used largely to buy luxury goods such as beer and bottled soft drinks. Expenditures on nutrition, savings and investment in productive processes were rare. This highlighted the fact that an effective strategy in the fight against poverty would require far more than merely innovation, training and subsidies aimed at increasing production and productivity [27].

In 1996, we promoted the creation of a community of inquiry within a community of practice [24] to make a diagnosis of poverty. This community consisted of 31 households, members of which regularly attended two-hour weekly meetings for three months We began with the question: What are the main drawbacks limiting their wellbeing?. The community then began identifying the principal causes of their problems and some possible solutions. It soon became evident that to improve their wellbeing they needed greater income (i.e. production and productivity) and better health (prevention of illnesses and malnutrition) which could be attained through education (participatory training) and investments (subsidies, loans and savings).

By 1998, the number of households participating in the project had increased from 31 to 69 , and the results used to produce the present model were generated from 63 to 69 households. From 1998 to 1999, a nutritionist gave training workshops on the criteria for estimating individual nutritional status, types of food and their effects in nutrition, the nutritional requirements of children and pregnant women, and the effects of junk food in nutrition.

In 1997 and 1998, the Regional Fund of the National Indigenous Institute (Instituto Nacional Indigenista - INI) granted loans for no-burn milpa agriculture and backyard livestock production. In 1997, the W.K. Kellogg Foundation donated USD\$ 45,000 for use in loans for self-employment in the implementation of innovations.

Changes in household investment were evaluated by estimating household investment levels (at constant 1997 prices) in 1997, 1998 and 1999 [27]. Investment levels were estimated based on local prices (considering state of deterioration) for construction, land, production infrastructure, equipment and household tools. Using date of birth, sex, weight and height, nutrition level percentages for children under five years of age were estimated from 1996 to 1999 for the 63 to 69 participating households. Weight and height for age tables were used to calculate $Z$ values [28], and children with $Z$ values less than 2 qualified as undernourished.

In 1999, a group of housewives began a savings fund called the Community Bank (Banco Comunitario) to mitigate household vulnerability using a simple savings and loan scheme [29]. Through training, this innovation was transferred to other development projects with financial backing from the W.K. Kellogg Foundation. The Community Bank made loans to micro-companies such as a corn-lying mill, a stationary store, a seamstress and household poultry and swine producers.

The W.K Kellogg donations ended in late 2004. As a result, research assistant salaries and expenses could no longer be covered by the project, although CINVESTAV-Merida continued to finance the project coordinator, allowing for weekly visits to Yaxcabá as an advisor to the cooperative

\section{RESULTS}

\section{A. Development, poverty, wellbeing and households}

Participatory diagnosis of the population of Yaxcabá showed that their poverty manifested in many ways, but could be grouped in terms of 1) low self-esteem and leadership; 2) malnourishment and high disease incidence; 3) low production and productivity, low or no salary (low income); and 4) high household vulnerability due to scarcity of financial resources (low capital and savings, also expensive loans). As defined above, wellbeing is a condition in which these elements of poverty have been remediated: people can cover their basic needs in education (self-esteem and leadership), physical and mental health (diet, disease prevention and treatment), income (production for subsistence, productivity and employment) and capital (low vulnerability, savings, loans and subsidies).

Participatory inquiry has revealed that the household, or domestic group, is the basic element of social development against poverty. A household principally consists of a family, the basic biological reproductive unit of the human species. Among groups of people, the household is also the basic unit of material survival and cultural transmission. It provides the environment required for children to grow and learn. It is where family members come to sleep at night and/or recover from injuries or disease. In a general sense, it can be seen as a system focused on meeting the needs of its members. A 
household has no clear physical limits since it can include members who send money from afar or adults who only spend weekends at home but contribute to maintaining the overall household. A person belongs to a household if she or he shares in its resources and acknowledges the presence of a leader or head of household. Household members are dynamic entities, linked by a network of relationships including affection, interdependence and hierarchy, and as such may be seen as systems.

Additionally, participatory inquiry has shown that households exist and are conditioned by the surrounding environment in which they thrive. Households form parts of a community, which can be seen as elements in a larger system. As such, existing households are dynamic, balanced systems in equilibrium with the surrounding environment. The household system is internally organized by its members, but is open to the environment from which it draws its needs; therefore, it is subject to availability of goods from the physical, biological, economic, social and political facets of the environment where it is located. The bonds between household members exhibit network relationship patterns similar to neuronal networks. A neuronal network pattern imposes non-linear (i.e. complex) interactions (or synergies) on to household behavior. A community of households consists of a group of interrelated households which also follows a neuronal network pattern. Both the household and the community therefore operate like complex social systems. The development against poverty system is a complex system because it exhibits properties analogous to the general properties of all complex systems [30]. In these systems, the values of certain variables and parameters generate attraction spaces (i.e. attractors) which are informally understood as states in which the system attains a dynamic equilibrium or collapses. Poverty and resource accumulation are attraction sites, that is, places within the development system which manifest a dynamic, stable condition.

\section{B. Households as agents within the system}

Households are treated as agents within the social development against poverty system. A household's development level is conditioned by its members' level of satisfaction in terms of education, health, income and capital. These variables are continuously changing with time and also interrelate, which creates interactions or synergies.

The social, economic, physical and biological facets in which households are immersed define system environment variables. At a local level, biological and physical variables remain relatively constant, with occasional disturbances due to events such as disease (e.g. cholera) and meteorological phenomena (e.g. hurricanes and drought). The economic and social variables which affect development include education (schools) and health structures (public health, clinics), income (markets) and the savings and credit structure (financing). The increase in poverty levels reported in official sources [5] are due mainly to changes in social and economic variables since physical and biological variables have experienced only minor changes.

\section{Development against poverty as a system}

Development against poverty treats a community of households as a group of agents. Each household is different and thus has different values for the variables. In a poor community, most of the households are poor and only a few have attained wellbeing; its frequency distribution has a lower end mode, meaning the poorest form the majority (Table 1). Under these circumstances, the strategy to fight against poverty needs to be focused on the poorest households in the community but with access for all households. This approach helps to produce a distribution with a mode in the middle, which is a middle class. No household wants to be poor and those that are poor use all their available resources to rise out of poverty. The only alternative these kinds of households have to rise out of poverty is the injection of external resources redirected from households with more resources.

Programs against poverty need to consider all household members, both heads (executives) and dependents (consumers), since all interact in the development process. Household members are organized by division of labor and any change in the parts affects the household as a whole. On the one hand are negative interactions; for example, if a member is sick they require care from another member, which affects income. On the other are positive interactions; for example, if a member increases her/his income this is commonly used to improve household conditions (e.g. treating sickness). When compared to the individual effect of a single variable, positive interactions are the most effective in fighting against poverty. In this project, any advance was celebrated with the community to boost their self-esteem and leadership capacity.

A graphic representation of the development against poverty process helps to better understand it (Figure 1). In Figure 1, a large oval represents the household, characterized by the variables education level, health status, income and investment level. Within the household, double-ended arrows express the relationships and interactions between these variables. The environment in which the household is immersed consists of the education system (schools), a health system (public health), access to income (market system) and a financial system (banks). Large arrows represent the energy flows from this environment into the household.

The household variables interact in cycles (inside oval), and external dynamic variables (outside oval) are part of the surrounding environment. Household needs occur in cycles such as eating, rest, sickness, milpa and honey production. In the project, emphasis was placed on what had been learned during one cycle and how to incorporate it into the next cycle. Each cycle conditions household status for the following cycle such that effects become causes. Household crises occur in response to change, both in internal and environmental variables. Innovations that have been proposed to improve household conditions should therefore be analyzed and tested by those who are going to use them to eliminate the risk of a household entering crisis. It should also be taken into account that the poverty of some households results in short-term 
benefits for richer households (e.g. payment of lower wages). The internal and environmental variables present at any given moment determine household function; development requires changes in the values of these variables. To face this challenge, household members require motivation, although this can result in conflict. Any development project therefore needs to be explained in detail to the applicable authorities and community leaders to prevent misunderstanding.

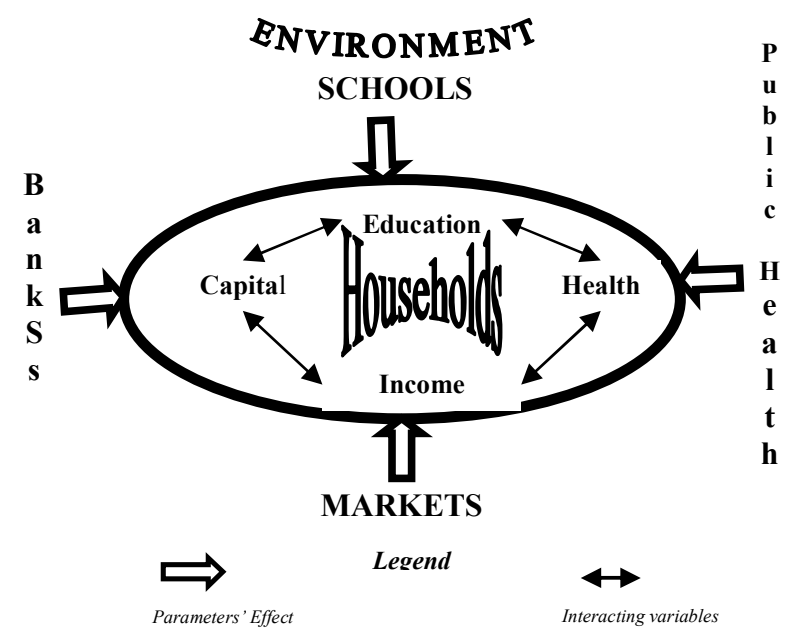

Figure 1. The social development against poverty system.

\section{Project impact}

The Project impact was estimated using three household parameters: changes in income level; changes in undernourishment in children less than 5 years of age; and changes in savings and credit levels.

Table 1. Proportion (\%) of households in different capital ranges in the years 1997, 1998 and 1999 (at constant 1997 prices).

\begin{tabular}{|c|c|c|c|c|c|c|}
\hline $\begin{array}{l}\text { Investme } \\
\text { Ranges. }\end{array}$ & $\begin{array}{l}5,000- \\
10,000\end{array}$ & $\begin{array}{l}10,000- \\
15,000\end{array}$ & $\begin{array}{l}15,000- \\
20,000\end{array}$ & $\begin{array}{l}20,000- \\
25,000\end{array}$ & $\begin{array}{l}25,000 \\
30,000 \\
\end{array}$ & $>30,000$ \\
\hline 1997 & $43.5 \%$ & $27.5 \%$ & $11.6 \%$ & $10.1 \%$ & $2.9 \%$ & $4.3 \%$ \\
\hline 1998 & $23.8 \%$ & $17.5 \%$ & $23.8 \%$ & $14.3 \%$ & $4.8 \%$ & $15.9 \%$ \\
\hline 1999 & $14.3 \%$ & $12.7 \%$ & $11.1 \%$ & $25.4 \%$ & $14.3 \%$ & $22.2 \%$ \\
\hline
\end{tabular}

Capital level among poor households exhibited a balance between income and expenses used to meet immediate needs since any surplus was used to improve the dwelling or production unit (Table 1). Among a total of 62 households, the largest proportion $(43.5 \%)$ of investment in 1997 was in the lowest range (5,000-10,000 pesos). In 1999, this range included only $14.3 \%$ of households whereas $25.4 \%$ were in a higher range (20,000-25,000 pesos). The distribution of household investments in 1998 was between those of 1997 and 1999. This pattern shows a transition from a log-normal distribution towards a normal distribution

Changes in health condition were evaluated using the proportion (\%) of children $(<5$ years of age $)$ with undernutrition; that is, values less than $-2 \mathrm{Z}$ for chronic malnutrition (height-for-age) and acute malnutrition (weightfor-age), [31], (Figure 2). No clear changes were observed in chronic malnutrition, although a slight decrease in acute malnutrition occurred. We now know that it is extremely difficult to improve the nutritional condition of children older than 2 years of age [31],[32], meaning a more sensitive indicator would be the nutritional level of children younger than 2 years.

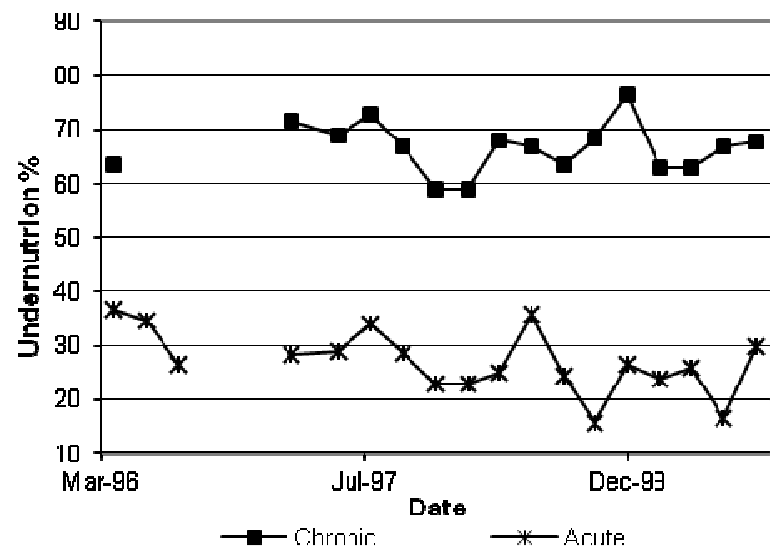

Figure 2. Changes in the percentages of children under 5 years of age with chronic or acute malnutrition

Poor households experience alternating cycles of stress and relative comfort. Capital (savings) is therefore a fundamental need since any unforeseen event (e.g. sickness) can become a crisis that threatens the life of a household member, or the household itself. Availability of savings and credit decreases household vulnerability. In the present case, household safety level was estimated based on the levels of savings and credit granted in the Community Bank. Changes in the number of savers, total amount of savings and total credit granted from February 1999 to July 2003 showed a clear increase in all three parameters, representing a decrease in household vulnerability (Figure 3).

E. Qualitative analysis of the model.

(i) Poverty as steady dynamic state.

The condition of poverty in households is a state of stable dynamic equilibrium in and outside the household. In Yaxcabá, the dynamic internal household variables exhibit low wellbeing values. They are, in other words, on the verge of collapse, or household disintegration.

(ii) Education.

The life conditions of the poor vis-à-vis those of other social groups make the former feel near worthless, fomenting in them a perception of low self-esteem, and a lack of initiative and leadership. The poor also often do not have the knowledge needed to improve their health, productivity and vulnerability, an outgrowth of their very condition. Households, communities and societies reproduce themselves through education [33]. Poverty is a characteristic of a society and is therefore reproduced, indeed, it can even be inherited: 
in the United States, being born poor greatly increases the probability of being poor in the future [34].

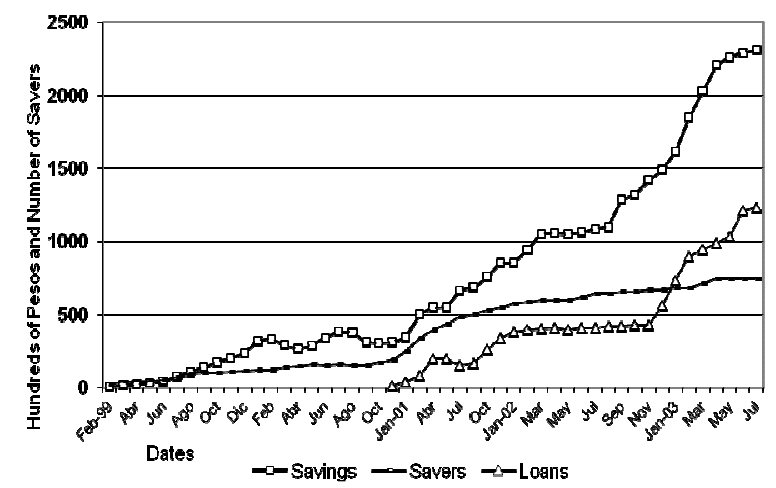

Figure 3. Number of savers, total savings and credit granted by Community Bank from February 1999 to July 2002.

(iv) Income (production and productivity).

The poor generally use obsolete means of production, so their products do not have competitive pricing in markets. They also do not have access to well-paying jobs, either because employers are not located in the area or they lack training. Obsolete methods and lack of training place them at a disadvantage when competing against other households.

(v) Access to capital.

The poor have limited access to capital resources such as savings and financing for use in adversity. Therefore, the smallest unforeseen circumstance can plunge a household into a crisis that can lead to its disintegration. The sudden and high cost of paying for medical treatment or recovering from a drought or hurricane frequently cannot be covered by their scant savings. The poor do have access to local financing systems but these are generally expensive and inefficient.

(vi) Interaction among variables.

Poverty is a self-perpetuating, dynamic and stable condition, in other words, a vicious cycle. All the variables in household cycles exhibit interactions that produce a greater impact than any single variable alone. It is therefore vital to consider these interactions in addition to the condition of individual variables. This reciprocal effect among variable values occurs in myriad forms. Low education values limit the knowledge the poor have of health care, reduce income and consequently limit access to capital. These conditions, in turn, limit household investment made in education of children and young people. Malnutrition makes the poor more susceptible to sickness, preventing them from dedicating more time to work and representing a potential drain on their already meager resources. Low production and productivity have a direct effect on product competitiveness and consequently on investment levels.

\section{F. The development process}

Assuming that poor households try to improve their level of wellbeing but are in a state of stable dynamic equilibrium, this state can be modified by changing the physical, biological, social and political environmental variables of the system which condition both poverty and community development. Household variable levels are linked to environmental parameters through the income obtained from production and the market, and directly linked to the social services of education, health and financing (including subsidies).

When the fight against poverty is focused on all households, those with higher levels of education, health, capital, production and productivity, and greater access to jobs or financing will take greater advantage of opportunities to improve their wellbeing. This is why changes need to be focused on the poorest households in a process that begins by using words to build the expectation of improved wellbeing in poor households followed by application of participatory research to implement innovations in the productive processes with which household members are familiar. Participatory research generates the type of innovations that are most applicable in the social and economic conditions in which poor households are immersed, as well as being a way of promoting innovations in other poor households.

Another aspect to consider is that any innovation requires investment in materials, equipment and/or labor. Given that poor households exist on the verge of collapse, they do not have the means to adopt innovations and are usually reluctant to take on the risks of change since it means putting their very existence in jeopardy. This investment therefore needs to be planned for through subsidies. Well implemented participatory research generates innovations that increase both in-kind and cash income for use in improving wellbeing rather than spending on luxury expenses. Avoiding unwise use of this new income requires participatory training in the community of poor households to counteract their educational deficiencies in values and attitudes, as well as knowledge. This also functions to neutralize or counteract the effects of adverse advertising, particularly for items such as soft drinks and junk food which have an especially damaging effect on poor households. Existence of a surplus offers the opportunity to save to cover unforeseen expenses such as treating an illness. Poor households have a greater need for these kinds of savings than those with greater wellbeing because an unforeseen expense can affect food availability. All poor households already have some savings systems, but they are very inefficient and costly. Their lack of sufficient resources to improve their wellbeing means that poor households initially require subsidies to cover the expenses of the participatory research that will help them to address their educational deficiencies, particularly in terms of self-esteem, diet and disease prevention.

In a village level system such as Yaxcabá, households exist in an environment with physical, biological, sociopolitical and economic parameters. Unless there are large 
investments such as a large irrigation project, the physical and biological parameters remain relatively constant with sporadic disturbances (e.g. hurricanes, drought, cholera, dengue fever). In contrast, economic and sociopolitical parameters can be modified through a social development process. In Yaxcabá, and probably in much of Mexico, household income is limited by a chronic lack of employment and uncompetitive product costs. Formal education is focused on forming workers rather than innovators/entrepreneurs since it is oriented toward mere instruction and not strengthening a change in attitudes and values to build self-esteem and leadership skills. Health care is focused mainly on curing diseases, a costly venture which benefits pharmaceutical companies, while little emphasis is placed on preventing malnourishment and disease. Support for the productive process is focused on large companies mainly via stimuli for export markets rather than development of local markets and production for subsistence. Financial systems are oriented towards credit with nonexistent or very inefficient savings schemes; the much higher credit vs. savings rates testifies to this. The values of these social and economic parameters are intended to generate profit from households with the highest levels of wellbeing, thereby reinforcing inequality, rather than produce greater wellbeing for all households in a society. Development must overcome these limitations in cycles by applying innovation to more efficiently meet the needs of poor households in key areas: education, by improving their values and attitudes; health by prevention of malnutrition and disease; production, by improving their traditional production systems and increasing their productivity; and financial, by reducing vulnerability through accessible savings and credit instruments and stimulating production. The complex systems approach predicts that when faced with collapse, a social system either enters into chaos and restructures itself or disappears.

A version of this conceptual model was successfully simulated by a dynamic mathematical model [35]. The results showed that changes only in income increase household capital in richer households, but leave it almost unchanged in poorer ones, thereby exacerbating socio-economic differences. Improving only health care increases income in poorer households although average household income remains constant, since the income contrast between households is reduced. The model also showed that effectively fighting poverty requires improvements in education, health, income and subsided loans. Overall, the greater the improvements in environmental parameters the more effective the poverty mitigation strategy will be.

\section{DISCUSSION.}

Comte's "positivism" with components including reduction, repetition and refutation, has dominated poverty research. Its approach of treating poverty merely as the result of low income is a disservice to the fight against poverty. Participatory research into poverty provides a better understanding of the limitations the poor must overcome. It also has shown that effects become causes through cycles which generate non-linear (i.e. complex) interactions between variables, and that households are organized internally but are open to the environment from which they obtain their needs. Households are in a state of constant flux in which their members are closely related and learn. Finally, they are grouped into communities. These are the properties of a complex system, and they need to be applied to the fight against poverty. Acceptance of its complexity will help the fight against poverty and enable the application of five principal points: 1) creation of programs focused on the poorest but open to all; 2) use of a completely participatory scheme that considers all members of poor households as beings in possession of knowledge relevant to attaining their wellbeing; 3) participatory generation of innovations that ideally address education, production, health and financing with the purpose of optimizing interaction between these variables; 4) participatory use of cycles to improve processes by testing, analyzing and implementing changes; and 5) acceptance of continuous change in the surrounding social and economic environments as well as in internal household conditions.

To fight poverty effectively, efforts need to be focused on improving basic public education, health, production and productivity, and finances. Education methodologies need to improve self-esteem and combat inadequate eating habits. Public health care should emphasize illness prevention rather than treatment since it is less expensive and less time consuming, especially for the poor. Improvements in production and productivity can begin by applying participatory processes to improve traditional production technologies, since these are adapted to the local physic, biotic and social environment; products should be marketed locally first and second in other markets. Public financial systems need to increase savings, particularly those of the poor, to reduce their vulnerability, and provide low-cost loans to raise production and productivity.

\section{CONCLUSIONS}

Development against poverty as a complex system concept attained through participatory research proposes a new conceptualization of poverty, a participatory and dynamic process, and a focus on multiple goals. It operates through application of successive approximations. Poverty is a condition of the household which involves deficiencies in selfesteem and leadership capacity, disease prevention and treatment, competitive ways of earning income, and low investment levels which create vulnerability in unforeseen circumstances. A development against poverty process considers all of these aspects. Households are dynamic social structures immersed in a changing environment with social, economic, biological and physical facets. The fight against poverty therefore must begin in the specific situation in which households exist and apply a flexible strategy that can adapt to households' changing needs. Finally, increasing the efficiency and relevance of programs against poverty requires that the poor as a group lead these programs. They will be affected by actions within the programs and should therefore participate in decision making, with "experts" acting as facilitators and 
advisors. Federal outlays for development have been enormous but poverty continues to increase; this could begin to change for the better if poor households became the drive behind development in Mexico.

\section{REFERENCES}

[1] World Bank, 2002. World Development Report 2000/ 2001: Attacking Poverty: Opportunity, Empowerment, and Security”. Washington, D. C.

http://siteresources.worldbank.org/INTPOVERTY/Resources/WDR/overview .pdf Last accessed May 25, 2012

[2] World Bank. 2011. Poverty \& inequality trends. http://web.worldbank.org/WBSITE/EXTERNAL/TOPICS/EXTPOVERTY/0, ,contentMDK:22569747 pagePK:148956 piPK:216618 theSitePK:336992,0 0.html Last accessed May 25, 2012

[3] Székely P. M. 2005. "Pobreza y desigualdad en México entre 1950 y 2004”. Documento de Investigación 24. Pp 1-34. Secretaría de Desarrollo Social. México, D. F.

http://es.scribd.com/doc/44631881/Pobreza-y-desigualdad-en-Mexicoentre-1950-y-2004 Last accessed March 8, 2013.

[4] CONEVAL (2009).Comunicado de prensa No. 006/09. REPORTA CONEVAL CIFRAS DE POBREZA POR INGRESOS 2008. D.F. http://www.coneval.gob.mx/cmsconeval/rw/resource/coneval $/$ med pobreza/3 494.pdf Last accessed May 21, 2012.

[5] CONEVAL (2012). Informe de Evaluación de la Política de Desarrollo Social en México 2012. Consejo Nacional de Evaluación de la Política Social en México. Gobierno de México. pp 28-30. http://web.coneval.gob.mx/Informes/Evaluacion/IEPDS2012/PagesIEPDSMex2012-12nov-VFinal lowres6.pdf Last accessed March 8, 2013.

[6] SEDESOL 2007. Programa Sectorial de Desarrollo Social 2007 20012. Pp 1- 60 .

http://www.sedesol.gob.mx/work/models/SEDESOL/Resource/1600/1/images /Prog_Sectorial_WEB.pdf Last accessed on March 8, 2013.

[7] Rihani, S. 2002. Implications of adopting a complexity framework for development. Progress in Development Studies 2(2), pp. 133-143.

[8] Rihani, S. and Geyer, R. 2001: Complexity: an appropriate framework for development? Progress in Development Studies 1(3), 237-45.

[9] Gibson K. A. Cahill, D. McKa 2010. Rethinking the dynamics of rural transformation: performing different development pathways in a Philippine municipality. Transactions of the Institute of British GeographersVol. 35, Issue 2: 237-255.

[10] Birch-Thomsen T. and S. P. Kristensen. 2005. Planning with complexity - how do we deal with stakeholder and spatial heterogeneity in land use planning? Danish Journal of Geography 105(2):23-37. http://rdgs.dk/djg/pdfs/105/2/03.pdf Last accessed March 8, 2013.

[11] Reason P. and H. Bradbury Ed. 2001 Handbook of Action Research. Participative Inquire and Practice. SAGE Publications. London.

[12] Capra F. (1998). La trama de la vida. Una perspectiva de los sistemas vivos. Anagrama. Spain.

[13] Morin E. 2004. La Espistemología de la Complejidad. Gazeta de Antropología.V. 20: 2

http://digibug.ugr.es/html/10481/7253/G20 02Edgar Morin.html Last accessed: March 9, 2013.

[14] Cuanalo de la C. H., W. Llanes Ch., I. Henández M., J. Canal K., B. Ek D., A. Uicab C. and E. Díaz H. (1998). "El Desarrollo Rural Perdurable en la Península de Yucatán”. In: Desarrollo Rural Sustentable: Experiencias, Enfoques y Perspectivas. S. A Pedroza., J. Ruíz T. and L. Alaniz G. (eds), pp. 78 -88. Universidad Autónoma Chapingo. México.

[15] INEGI 2010 Censo de Población y Vivienda 2010. Base de datos a nivel localidad. Integración territorial para el estado de Yucatán. Instituto Nacional de Geografía y Estadística. Mexico.

[16] Cuanalo de la C. H. E. and A. Uicab C. (1998b). Participatory Research to Eliminate the Burn in Slash and Burn Agriculture in Yucatan, Mexico. Proceedings. $16^{\text {th }}$ World Congress of Soil Science. Symposium 12, Montpellier, France, CD ROM.
[17] Cuanalo de la C.H.E. and R.A. Uicab C. (2005). Investigación Participativa en la Milpa Sin Quema. Terra Latinoamericana. V 23: 587-597.

[18] Fortes M. 1971. Introduction: In: J. Goody (ed.). The Developmental Cycle in Domestic Groups. Cambridge. Pp 1-14. At the University Press. Great Britain.

[19] Copestake J. (2009). Development and Wellbeing in Peru: Comparing Global and Local Views. Wellbeing and Development. Working Paper 09/48. http://www.welldev.org.uk/wednew/workingpapers/workingpapers/WeDWP 09 48.pdf Last accessed March 8,2013

[20] Werner J. 1993. Participatory Development of Agricultural Innovations: Procedures and Methods of On Farm Research. Deutsche Gesellschaft für Technische Zusammenarbeit and Swiss Development Cooperation. Eschborn, Germany

[21] Hanfling O. 1981. Logical Positivismo. Oxford Blackwells. Oxford, U.K.

[22] Fals B. O. (2001) Participatory (Action) Research in Social Theory: Origins and Challenges. Handbook of Action Research. Participative Inquiry and Practice. Pp 27-37. P. Reason and H. Bradbury (eds). SAG Publications. London.

[23] Friedman V. J. 2001 Action Science: Creating Communities of Inquire in Communities of Practice. Pp 159-170. Handbook of Action Research. Participative Inquiry and Practice. P. Reason and H. Bradbury (eds). SAG Publications. London.

[24] Friedman V. J. and T. Roger (2008). Action Science: Linking Causal Theory and Meaning Making in Action Research. Pp 252-265. Handbook of Action Research. Participative Inquiry and Practice. P. Reason and H. Bradbury (eds). Second Edition. SAG Publications. London.

[25] Cuanalo de la C.H.E. and R.A. Uicab C. (2005). Investigación Participativa en la Milpa Sin Quema. Terra Latinoamericana. Vol 23:p. 587597.

[26] Cuanalo de la C. H. E. and R. A. Uicab C. (2006). Resultados de la Investigación Participativa en la Milpa Sin Quema. Terra Latinoamericana. Vol 24:p. 401-408.

[27] Cuanalo de la C. H. E. and A. Siniarska. (2006b). Changes in a Rural Community Associated with Improvements in Production and Productivity. International Journal of Anthropology. Vol. 21. No. 2: p. 131140.

[28] WHO. 1995 Physical Status. The Use and Interpretation of Anthropometry. Report of a WHO Expert Committee. WHO Technical Report Series 854. WHO. Geneva, Switzerland.

[29] Castillo S. M. A. and M. Rabasa G. (2003) Ahorro y desarrollo, su potencial educativo y organizativo. In Cuanalo de la C. H. Ed. Desarrollo Social Contra la Pobreza. Red Mexicana de Proyectos de Desarrollo Social, A. C., CINVESTAV, W.K. Kellogg Foundation. Yucatan, Mexico.

[30] Parwani R. R. 2002. "Complexity. A Course".

http://staff.science.nus.edu.sg/ parwani/c1/book.html Last accessed March 8, 2013

[31] Cuanalo de la C. H. E, L. G. Dzul S., M. Quintana A. y Z. M. Cabrera A.2009. (200) La prevención de la desnutrición y la educación. MEMORIAS CD. Con. Intr. Educación Popular de las Américas Siglo XXI. Valladolid, Yucatán, México.

[32] Rivera D and M. T. Ruel 1997. Growth retardation starts in the first three months of life among rural Guatemalan children. Eur J Clin Nutr. 51:92-96.

[33] Freire P. 1970 Pedagogía del Oprimido. Siglo XXI. México, D.F., Mexico.

[34] Radcliffe C. and S. McKernan. 2010. Child poverty persistence: Facts and consequences. Urban Institute. Research of records. http://www.urban.org/uploadedpdf/412126-child-poverty-persistence.pdf Last accessed Mach 8, 2013

[35] Murrieta H. G. and Cuanalo de la C. H. E.(2011). Development against poverty: A dynamic simulation model. $14^{\text {th }}$. Conference. Latest Trends on Systems. WSEAS. Greece. 2010. Vol. II pp 501-509.

http://www.wseas.us/elibrary/conferences/2010/Corfu/SYSTEMS/SYSTEMS2-25.pdf Last accessed March 11, 2013.

\section{Creative Commons Attribution License 4.0 (Attribution 4.0 International, CC BY 4.0)}

This article is published under the terms of the Creative Commons Attribution License 4.0 https://creativecommons.org/licenses/by/4.0/deed.en_US 